TITLE:

\title{
Comparative contractile effects of halothane and sevoflurane in rat aorta(Abstract_要旨)
}

\author{
AUTHOR(S): \\ Vu Huu Vinh
}

\section{CITATION:}

Vu Huu Vinh. Comparative contractile effects of halothane and sevoflurane in rat aorta. 京 都大学, 2001, 博士(医学)

ISSUE DATE:

2001-03-23

URL:

http://hdl.handle.net/2433/150545

RIGHT: 
氏 名 Vü Huu Vinh

学位(専攻分野) 博士 (医学)

学位記番号、医 博第 2349 号

学位授与の日付 平成 13 年 3 月 23 日

学位授与の要件 学位規則 第 4 条第 1 項該 当

研究科. 専攻医学研究科外科系専攻

学位論文題目 Comparative contractile effects of halothane and sevoflurane in rat aorta

（ラット大動脈におけるハロタンとセボフルランの収縮作用の比較）

論文調査委員 教授) 野間昭典教授成宮 周教授福田和彦

\section{論 文 内 容 の 要 旨}

ハロタン, イソフルラン, セボフルランなどのハロゲン化揮発性吸入麻酔薬は血管平滑筋の収縮を抑制し, 血管の驰緩を きたすことが知られている。一方これらの麻酔薬は，実験の条件によっては平滑筋の収縮を誘導することも示されている。 八ロタンの血管収縮作用についてはこれまで，筋小胞体からのカルシウム放出によると考えられてきたが，それだけで説明 可能かどうかは明らかではない。申請者らはすでに，イソフルランによるラット大動脈の収縮は主に電位非依存性のカルシ ウムチャネルの活性化によるとする研究成果を発表している。本研究では, ハロタンとセボフルランの血管平滑筋収縮作用 を比較しそそれらによる収縮の機序について検討した。

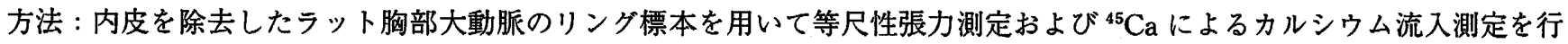
った。前者では, 標本をクレブス・リンゲル液内で圧トランスデューサーに装着し, 張力の変化を測定した。後者では, 標 本を ${ }^{45} \mathrm{Ca} に 2$ 分間暴露し，標本の放射活性を測定することによって平滑筋へのカルシウム流入量を評価した。いずれの実 験も，吸入麻酔薬により抑制を受ける電位依存性カルシウムチャネルの影響を除くため, 十分量のベラバミル存在下で行っ た。

結果 : 標本をフェニレフリンで前収縮させた状態でハロタンは濃度依存性の収縮を誘導したが，セボフルランは収縮をきた さなかった。 ${ }^{45} \mathrm{Ca}$ を用いた実験では，フェニレフリンはカルシウム流入量を増加させたが，引き続き遒入された $1 〜 2 \%$ のハロダはそれをさらに增強させた。このカルシウム流入はベラバミル存在下で発生したため, 電位非依存性カルシウム チャネルを介するものであると考えられた。八ロタンの効果は濃度依存性ではなく，4\%では增強作用は失なわれた。一方， セポフルランはいずれの濃度でもカルシウム流入量に影響を与えなかった。

ハロタンによる平滑笳収縮の機序をさらに詳しく検討するため，電位非依存性カルシウムチャネルの遮断薬である SKF96365 あるいは筋小胞体の貯蔵カルシウムを枯渴させるリアノジン，タプシガルギンを用いて同様の実験を行った。 SKF96365 は 1\%ハロタンによる収縮およびカルシウム流入をともに抑制した。リアノジンおよびタブシガルギンは $4 \%$ ハ ロタンによる収縮を抑制したが，1〜2\%のハロタンによる収縮を抑制しなかった。

結論 : 以上の結果より，八ロタンは $1 \sim 2 \%$ ハは主に電位非依存性カルシウムチャネルからのカルシウム流入によって平滑 筋収縮を誘導し，4\%では主に筋小胞体からのカルシウム放出によって収縮を誘導していることが示唆された。一方，七ボ フルランにはどちらの作用も確認できなかった。生体での吸入麻酔薬の心血管系に対する作用に，本研究で示された機序が 関係している可能性があると考えられた。

\section{論 文 審 查の 結 果 の 要旨}

揮発性吸入麻酔薬は血管収縮作用と血管驰紘作用を有することが知られている。本研究では血管平滑筋に抢ける揮発性吸 入麻醉薬の収縮作用の機序について，カルシウム動態の観点から検討した。 
摘出ラット胸部大動脈を用い，等尺性張力測定および放射性同位元素によるカルシウム流入量測定を行った。吸入麻酔薬 の有する電位依存性カルシウムチャネル抑制作用は血管収縮作用を修飾するため，同チャネルのブロッカーであるべラパミ ルを使用し，同チャネルの関与を除外して解析を行った。フェニレフリンで前収縮させた血管に対し，吸入麻醉真ハロタン は用量依存性の血管収縮を引き起こしたが，セボフルランは収縮も弛緩も起こさなかった。低濃度 $(1,2 \%)$ 八ロタンは カルシウム流入量を増加させ，血管収縮は電位非依存性カルシウムチャネルの活性化に基つくく考えられた。一方，高濃度 （4\%）八ロタンによる血管収縮は，カルシウム流入の増加を伴わず，細胞内貯蔵カルシウムを枯渴させる ryanodine ある いは thapsigarginの前処理によって抑制されることから，筋小胞体からのカルシウム放出が主原因であると考えられた。

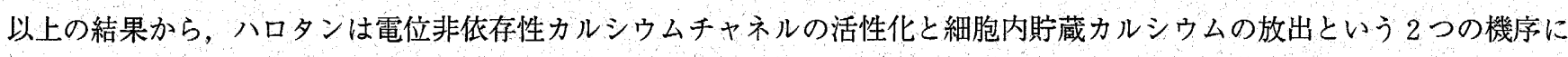
よって血管収縮を惹起することが明らかになった。

以上の研究は血管平滑笳に扔ける吸入麻酔薬の新しい作用を示したものであり, “臨床的にも重要な吸入麻醉薬の循環器系 に対する作用の解明に奇与するところが多い。

したがって, 本論文は博士 (医学) の学位論文として価値あるものと認める。

なお，本学位授与申請者は，平成13年 2 月16日実施の論文内容とそれに関連した試問を受け，合格と認められたものであ る。 